\title{
Opcje rzeczywiste w podejmowaniu decyzji inwestycyjnych na przykładzie budowy podziemnego magazynu gazu
}

\begin{abstract}
W artykule przedstawiono ideę opcji rzeczywistych oraz zaproponowano użycie opcji rozszerzenia skali przedsięwzięcia do oceny ekonomicznej budowy podziemnego magazynu gazu. Opcją rozszerzenia skali jest możliwość powiększenia pojemności czynnej magazynu w przyszłości. Okazuje się, że stosując symulację Monte Carlo do wyznaczenia wartości bieżącej netto przedsięwzięcia, dla podstawowej wielkości przykładowego stylizowanego magazynu uzyskuje się ujemną wartość oczekiwaną NPV. Uwzględnienie w procesie symulacji rozbudowanej wielkości magazynu zapewnia dodatnią wartość oczekiwaną projektu. Jednakże wycena rozbudowy magazynu gazu z użyciem opcji rzeczywistej prowadzi do jeszcze wyższej wartości analizowanego projektu ze względu na możliwość rezygnacji z rozbudowy w przypadku niesprzyjających warunków ekonomicznych.
\end{abstract}

Słowa kluczowe: opcje rzeczywiste, decyzje inwestycyjne, podziemny magazyn gazu.

\section{Real options in investments decision making on the example of the construction of an underground gas storage}

\begin{abstract}
The paper presents the idea of real options and proposes the use of an option, to expand the scale of a venture, to evaluate the construction of an underground gas storage. The option to expand the scale has the possibility of increasing the volume of gas storage in the future. It turns out, that using the Monte Carlo simulation to determine the net present value of the stylized project for primary storage volume, the negative expected NPV is achieved. Taking into account the extended size of the gas storage in the simulation process, it provides a positive expected value of the project. However, the expansion of gas storage valuation using the real option provides even a higher value of the project due to the ability to opt out of the expansion in the case of unfavourable economic conditions.
\end{abstract}

Key words: real options, investment decisions, underground gas storage.

\section{Wprowadzenie}

Symulacja Monte Carlo jest jedną z lepszych i powszechnie uznanych metod uwzględnienia ryzyka i niepewności w ocenie rentowności inwestycji. Biorąc pod uwagę dużą liczbę czynników ryzyka projektu naftowego, dotyczących nie tylko sytuacji rynkowej, ale także strony technicznej i geologicznej, stosowanie symulacji to oczywiste narzędzie oceny i ograniczania ryzyka (por. [5] i [9]). Jednak wadą metody Monte Carlo w analizie rentowności inwestycji rzeczowych jest jej „statyczność” decyzyjna. Wszelkie decyzje dotyczące przedsięwzięcia muszą być podjęte na początku analizy i co najwyżej modelowane z użyciem zmiennych losowych.
W rzeczywistości decyzja inwestycyjna składa się zwykle z ciągu decyzji zależnych od wyników wcześniejszego etapu inwestycyjnego. Przykładowo, eksploatacja złoża następuje dopiero po pozytywnych wynikach badań geologicznych, ale także przy sprzyjających warunkach rynkowych. Z drugiej strony, w sytuacji nadmiernego spadku tempa wydobycia możliwa jest wcześniejsza likwidacja złoża. Budowa podziemnego magazynu gazu o mniejszej pojemności pozwala zwykle na powiększenie pojemności czynnej w przyszłości, jeżeli pojawi się dodatkowy popyt na usługę magazynowania. W przypadku kierowania 
się jedynie kryterium wartości bieżącej netto NPV projektu wiele przedsięwzięć zostałoby odrzuconych, jednakże często są one realizowane ze względu na przewidywania menedżerów dotyczące rozwoju sytuacji w przyszłości. Decyzje te są jedynie jakościowe i wynikają z doświadczenia decydentów. Wskazane byłoby określenie ich w sposób ilościowy w celu precyzyjnego wycenienia wartości przedsięwzięcia.

W ostatnich latach problem ten znalazł rozwiązanie dzięki wykorzystaniu teorii opcji. Opcja jest pochodnym instrumentem finansowym dającym prawo, ale nie obowiązek, zakupu (opcja kupna) lub sprzedaży (opcja sprzedaży) określonego instrumentu bazowego - lub inaczej: podstawowego - (np. akcji) po ustalonej cenie, zwanej ceną wykonania, w ustalonym okresie, zwanym terminem wykonania. Opcja kupna (call option) daje jej posiadaczowi prawo nabycia instrumentu bazowego, natomiast opcja sprzedaży (put option) - prawo sprzedaży instrumentu bazowego po z góry określonej cenie wykonania (strike price lub excercise pri$c e$ ). Prawo to może być zrealizowane w dniu wygaśnięcia opcji (opcja europejska) lub w dowolnym dniu od daty zawarcia kontraktu opcyjnego do daty wygaśnięcia włącznie (opcja amerykańska).

Wartość opcji w dowolnym momencie pomiędzy chwilą jej zawarcia a momentem wygaśnięcia jest sumą jej wartości wewnętrznej (intrinsic value) oraz wartości czasowej (time value). Wartość wewnętrzna to wartość opcji, gdyby możliwe było jej natychmiastowe wykonanie. Wartość czasowa jest miarą możliwego wzrostu wartości opcji w okresie do jej wygaśnięcia. Wartość czasowa opcji maleje w miarę zbliżania do terminu wygaśnięcia opcji.

Wartości wewnętrzne opcji kupna i sprzedaży można przedstawić odpowiednio:

$$
\begin{aligned}
& C=\max (0, S-K) \\
& P=\max (0, K-S)
\end{aligned}
$$

gdzie:

$C$ - wartość opcji kupna,

$P$ - wartość opcji sprzedaży,

$S$ - cena instrumentu podstawowego (bazowego),

$K$ - cena wykonania.
Wartością czasową opcji jest różnica między ceną opcji na rynku a wartością wewnętrzną.

Teoria wyceny opcji opiera się na zasadzie braku arbitrażu, to znaczy braku możliwości zawarcia równoczesnej transakcji kupna instrumentów finansowych na jednym rynku i sprzedaży na drugim rynku - lub na tym samym rynku, ale pod inną postacią $-\mathrm{z}$ dodatnim prawdopodobieństwem zysku bez ponoszenia ryzyka straty. Inżynieria finansowa wypracowała wiele modeli wyceny opcji finansowych, w tym modele oparte na drzewie dwumianowym, modele Blacka-Scholesa i Mertona. W dalszej części wykorzystany zostanie popularny model drzewa dwumianowego Coxa, Rossa i Rubinsteina [3]. Szerzej metodyka wyceny opcji przedstawiona została w [6].

Rozwinięty aparat matematyczny dotyczący opcji finansowych przeniesiono na grunt inwestycji rzeczowych i wyceny wartości przedsiębiorstw. Narzędziem pozwalającym na uwzględnienie elastyczności decyzji w procesie inwestycyjnym stały się opcje rzeczywiste, nazywane także opcjami realnymi lub rzeczowymi. Główne opcje rzeczywiste można sklasyfikować następująco [8]:

- opcja opóźnienia (option to defer), odpowiednik amerykańskiej opcji kupna,

- opcja rozszerzenia skali przedsięwzięcia (option to expand), odpowiednik amerykańskiej opcji kupna,

- opcja zmniejszenia (option to reduce), odpowiednik amerykańskiej opcji sprzedaży,

- opcja zatrzymania i wznowienia działalności (option to shut down and restart), odpowiednik amerykańskiej opcji kupna,

- opcja rezygnacji (option to abandon), odpowiednik amerykańskiej opcji sprzedaży,

- opcja wzrostu (growth option), odpowiednik amerykańskiej opcji kupna,

- opcja przełączenia (option to switch), połączenie amerykańskich opcji kupna i sprzedaży.

W praktyce można mieć do czynienia z połączeniem kilku opcji inwestycyjnych (por. [13]), co nosi nazwę opcji złożonej (compound option). W sytuacji gdy podjęcie decyzji inwestycyjnej jest powiązane z kilkoma czynnikami ryzyka, istnieje możliwość zastosowania tak zwanej opcji tęczowej (rainbow option).

\section{Wycena opcji z użyciem drzewa dwumianowego}

Powszechnie znany model wyceny opcji to model Blacka-Scholesa [1], który służy do wyceny opcji europejskich z jednym ściśle oznaczonym terminem wykonania. Model ten można wykorzystać do wyznaczania wartości opcji rzeczywistej w sytuacji, gdy decyzja inwestycyjna podejmowana jest $\mathrm{w}$ określonym, krótkim czasie w przyszłości.
Jeżeli jednak decyzja inwestycyjna może zostać zrealizowana w dłuższym okresie, należy zastosować metody wycen opcji typu amerykańskiego. Opcje takie mogą być realizowane $\mathrm{w}$ dowolnym momencie do terminu zapadalności, podobnie jak decyzje inwestycyjne dotyczące na przykład budowy podziemnego magazynu gazu lub rozpoczęcia 
eksploatacji złoża, które mogą zostać podjęte w ciągu kilku czy nawet kilkunastu lat.

Najczęściej stosowanym modelem wyceny opcji amerykańskich jest iloczynowy (geometryczny) model dwumianowy (model drzewa dwumianowego) zaproponowany przez Coxa, Rossa i Rubinsteina [3]. W modelu dwumianowym przyjmuje się, że wartość instrumentu podstawowego $S$ zmienia się w taki sposób, że w każdej chwili może podążyć tylko w kierunku jednego z dwóch możliwych stanów: w górę (przyrost $u>1$, z prawdopodobieństwem $p$ ) lub w dół (spadek $d<1$, z prawdopodobieństwem $q=1-p$ ), osiągając jedną z wartości: $u S$ lub $d S$. Zakłada się także, że $u d=1$, stąd $u=1 / d[3]$.

Dzieląc czas do wygaśnięcia opcji $T$ na małe odcinki $\Delta t$ oraz przyjmując brak możliwości arbitrażu i neutralność inwestorów względem ryzyka, oczekiwana stopa zwrotu z instrumentu podstawowego musi być równa stopie wolnej od ryzyka ${ }^{1}$. Idea wyceny opcji opiera się na konstrukcji portfela replikującego, składającego się z jednostek instrumentu podstawowego oraz jednostek instrumentu finansowego wolnych od ryzyka, takiego, że jego wartość w dowolnej chwili jest równa wypłacie instrumentu pochodnego. Biorąc to pod uwagę, wartość instrumentu podstawowego powiększona o stopę wolną od ryzyka musi być równa wartości oczekiwanej tego instrumentu w chwili $\Delta t$. Mamy zatem [14]: $S e^{r \Delta t}=p u S+(1-p) d S$, gdzie $r$ jest stopą wolną od ryzyka. Idea procesu wartości instrumentu podstawowego przedstawiona została na rysunku 1 .

Po podzieleniu przez cenę instrumentu podstawowego $S$, przekształceniach i dla dostatecznie małego
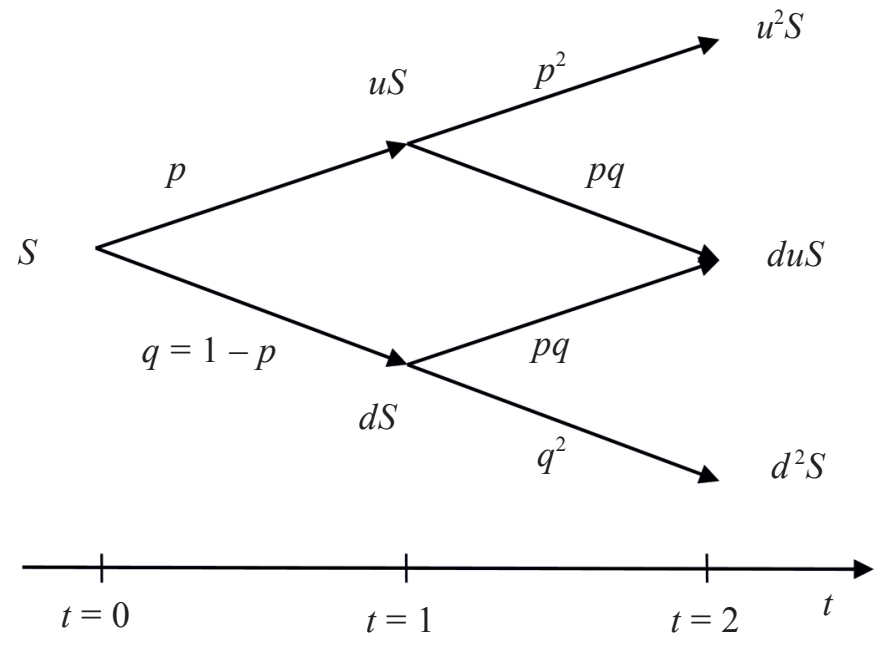

Rys. 1. Proces geometryczny zmiany wartości $S$ instrumentu podstawowego na drzewie dwumianowym

Źródło: opracowanie własne.

\footnotetext{
${ }^{1}$ Za stopę wolną od ryzyka przyjmuje się zwykle stopę procentową bonów skarbowych lub lokat bankowych.
}

$\Delta t^{2}$ otrzymujemy wzór na prawdopodobieństwo neutralne względem ryzyka:

$$
p=\frac{e^{r \Delta t}-d}{u-d}, u=e^{\sigma \sqrt{\Delta t}}, d=e^{-\sigma \sqrt{\Delta t}}
$$

gdzie:

$u, d$ - parametry wzrostu i spadku,

$r$ - stopa wolna od ryzyka,

$\sigma-$ zmienność instrumentu bazowego.

Wartość opcji wyznacza się, zaczynając od węzła końcowego w chwili $T$, cofając do początku. Wartość opcji w węzłach wcześniejszych oblicza się jako wartość oczekiwaną z dwóch późniejszych węzłów zdyskontowaną stopą wolną do ryzyka $r$. W każdym węźle należy sprawdzić, czy korzystniejsze jest wcześniejsze wykonanie opcji, czy trzymanie jej kolejny okres $\Delta t$.

Podstawowy problem wyceny opcji rzeczywistych to spełnienie założenia modelu teoretycznego, według którego muszą istnieć na rynku bazowe aktywa finansowe, względem których wyznaczana jest wartość opcji. Ich istnienie zapewnia brak możliwości arbitrażu. W przypadku opcji rzeczywistych należałoby znaleźć na rynku instrument bliźniaczy (pośród np. instrumentów giełd towarowych energii, surowców lub innych), który generuje przepływy pieniężne doskonale skorelowane $\mathrm{z}$ instrumentem bazowym opcji rzeczywistej. W przypadku opcji rzeczywistych często nie ma takich aktywów bliźniaczych. Copeland i Antikarov [1] zaproponowali metodykę odrzucającą potrzebę istnienia instrumentu bliźniaczego zwaną marketed asset disclaimer (MAD), w której zakłada się, że instrumentem bazowym opcji jest sam projekt inwestycyjny oraz jego wartość bieżąca brutto PV.

Zdefiniujmy wartość rynkową projektu $M V_{t}$ w czasie $t$ jako ${ }^{3}$ :

$$
M V_{t}=\sum_{n=t+1}^{T} \frac{C F_{n}}{(1+r)^{n}}
$$

gdzie:

$C F_{n}$ - przepływy pieniężne netto w okresie $n$.

Stopą dyskontową jest stopa wolna od ryzyka, analogicznie jak w modelu dwumianowym wyceny opcji.

\footnotetext{
${ }^{2}$ Założenie o dostatecznie małym $\Delta t$ jest potrzebne po to, by stopy zwrotu mogły podlegać rozkładowi logarytmiczno-normalnemu. $\mathrm{W}$ efekcie dla $u=e^{\sigma \sqrt{\Delta t}}, d=e^{-\sigma \sqrt{\Delta t}}$ model Coxa, Rossa i Rubinsteina jest zbieżny do modelu Blacka-Scholesa [3].

${ }^{3}$ Formalnie należałoby zastosować dyskontowanie ciągłe i logarytmiczną stopę zwrotu, ale dalsze obliczenia dotyczą przepływów pieniężnych dla przedsięwzięcia inwestycyjnego w dyskretnych rocznych okresach.
} 
Niech $r_{t}$ będzie zmienną losową oznaczającą ciągłą stopę zwrotu z projektu pomiędzy okresami $t \mathrm{i} t-1$. Wtedy wartość bieżąca projektu $P V_{t}$ w okresie $t$ wynosi:

$$
P V_{t}=M V_{t-1} e^{r_{t}}
$$

Stopa zwrotu z projektu w okresie $t$ może zostać zdefiniowana jako:

$$
r_{t}=\ln \left(\frac{P V_{t}}{M V_{t-1}}\right)
$$

Wyestymowane w procesie symulacji Monte Carlo odchylenie standardowe tak określonej stopy zwrotu $r_{1}$ dla pierwszego roku działalności operacyjnej projektu jest traktowane w podejściu MAD jako zmienność instrumentu bazowego. Analizując wzór (2), łatwo można stwierdzić, że zmienność mierzona odchyleniem standardowym stanowi podstawowy parametr wpływający na wartość opcji, stąd poprawne wyznaczenie odchylenia standardowego decyduje o wiarygodności obliczonej wartości opcji. Podejście MAD spotyka się z krytyką i okazuje się, że zwykle prowadzi do zawyżenia zmienności [6], niemniej jednak w przypadku unikatowych projektów, dla których nie istnieje możliwość zna- lezienia adekwatnych instrumentów bazowych, podejście to nie ma sensownej alternatywy. Dlatego też metodyka MAD zyskuje popularność.

Podejście MAD nie powinno natomiast być stosowane wtedy, gdy na rynku istnieją instrumenty bliźniacze, które mogą być modelowane bezpośrednio. Możliwe jest wtedy bezpośrednie modelowanie parametrów posiadających instrumenty bliźniacze, adjustacja ich przepływów pieniężnych i modelowanie wtórne wartości przedsięwzięcia PV (por. [12]). Problem staje się jednak skomplikowany w przypadku występowania wielu instrumentów bliźniaczych, dla których konieczne byłoby tworzenie opcji złożonych (tęczowych).

Nawet $\mathrm{w}$ takiej sytuacji dyskusyjne pozostaje modelowanie ryzyka technicznego czy geologicznego. Interesujące podejście do modelowania opcji rzeczowych zawierających wiele czynników ryzyka, takich jak ceny surowca, ryzyko techniczne i ryzyko geologiczne towarzyszące projektom naftowym, przedstawione zostało w pracy [10]. Jest to jednak podejście trudne od strony formalnej i dla praktyków zdecydowanie prostsze, spójne i bardziej zrozumiałe może być podejście MAD.

\section{Ocena efektywności ekonomicznej budowy magazynu gazu z wykorzystaniem opcji rozszerzenia skali przedsięwzięcia}

Teoria wyceny opcji rzeczywistych zostanie zastosowana do wyznaczenia wartości podziemnego magazynu gazu wraz z możliwością (opcją) jego rozbudowy w przyszłości w sprzyjającej sytuacji rynkowej. Teoria opcji może zostać wykorzystana także do podjęcia decyzji o konwersji złoża gazu w magazyn [11] lub wyznaczeniu strategii cenowej dla usługi magazynowania $\mathrm{w}$ relacji do cen rynkowych gazu [4].

Analizie poddano stylizowany projekt budowy kawernowego podziemnego magazynu gazu o pojemności czynnej $100 \mathrm{mln} \mathrm{m}^{3}$, planowanych nakładach inwestycyjnych wynoszących 550,5 mln zł i czasie budowy 7 lat. Przyjęto $120 \%$ wykorzystania pojemności czynnej magazynu ${ }^{4}$ oraz średnią cenę za usługę magazynowania wynoszącą około $560 \mathrm{z} / 1000 \mathrm{~m}^{3}$. W rzeczywistej analizie rentowności należałoby oczywiście uwzględnić wszystkie składniki ceny zawierające opłatę za rezerwację pojemności, mocy zatłaczania/odbioru i kwoty zatłoczone/odebrane. Ponadto możliwe jest wzięcie pod uwagę niepełnego wykorzystania pojemności i mocy magazynu.

\footnotetext{
${ }^{4}$ Ze względu na możliwość kilkukrotnego zatłaczania i odbioru w sezonie zimowym.
}

Zakłada się, że w 8. lub 9. roku istnieje możliwość rozbudowy PMG o kolejne $100 \mathrm{mln} \mathrm{m}^{3} \mathrm{w}$ wyniku wykonania kolejnych kawern. Potencjalna rozbudowa magazynu będzie zależała od sytuacji rynkowej, to znaczy zapotrzebowania na usługę magazynowania i poziomu cen na rynku gazowym. Nakłady na rozbudowę wyniosą według planu 218,3 mln zł i będą ponoszone w ciągu 4 lat. W wariancie tym założono potencjalnie niepełne wykorzystanie pojemności czynnej wynoszące $80 \%$. W obu wariantach przyjęto 30-letni horyzont analizy oraz 6-procentową - realną stopę dyskontową.

Zgodnie z założeniami podejścia MAD w pierwszej kolejności zbudowano modele symulacyjne dla projektu podstawowego oraz projektu rozbudowy. W przypadku pierwotnego projektu dotyczącego budowy podstawowej wersji magazynu jako zmienne losowe przyjęto:

- stopień wykorzystania pojemności czynnej - rozkład trójkątny $(90 \%, 120 \%, 140 \%)$, przychody generowane w cyklu 3-letnim dla 3 niezależnych zmiennych losowych; możliwe byłoby generowanie wszystkich 26 niezależnych zmiennych losowych dla każdego roku osobno, ale wydłużyłoby to czas obliczeń, nie poprawiając znacząco dokładności; w rzeczywistych obliczeniach powinno uwzględnić się natomiast długość cyklu klimatycznego, 
- $\quad$ stopę wzrostu ceny za usługę magazynowania - rozkład trójkątny $(-2 \%, 2 \%, 5 \%)$,

- roczne koszty stałe (bez amortyzacji) - rozkład trójkątny (5,5 mln zł, 6,5 mln zł, 7,25 mln zł),

- koszty zmienne - rozkład trójkątny $\left(6 \mathrm{zł} / 1000 \mathrm{~m}^{3}\right.$, $8 \mathrm{zl} / 1000 \mathrm{~m}^{3}, 9,5 \mathrm{zl} / 1000 \mathrm{~m}^{3}$ ),

- zmianę nakładów inwestycyjnych - rozkład trójkątny $(-10 \%, 0 \%, 30 \%)$.

Użycie trójkątnych rozkładów losowych wynika z praktyki inżynierskiej - stosunkowo proste jest dla specjalisty określenie wartości najmniejszej, największej i najbardziej prawdopodobnej dla zmiennej w jego obszarze wiedzy (por. [5]). Zastosowanie innych rozkładów losowych możliwe jest w przypadku tych zmiennych, dla których istnieje wystarczająco liczny zbiór danych historycznych.

Następnie dla projektu dotyczącego rozbudowy magazynu przyjęto zmienne losowe o następujących parametrach:

- stopień wykorzystania pojemności czynnej - rozkład trójkątny $(50 \%, 80 \%, 100 \%)$, przychody generowane w cyklu 3-letnim dla 3 niezależnych zmiennych losowych,

- stopa wzrostu ceny za usługę magazynowania - rozkład trójkątny $(-2 \%, 2 \%, 5 \%)$,

- roczne koszty stałe (bez amortyzacji) - rozkład trójkątny (5,5 mln zł, 6,5 $\mathrm{mln} \mathrm{zl}, 7,25 \mathrm{mln} \mathrm{zl})$,

- koszty zmienne - rozkład trójkątny $\left(6 \mathrm{zł} / 1000 \mathrm{~m}^{3}\right.$, $8 \mathrm{zl} / 1000 \mathrm{~m}^{3}, 9,5 \mathrm{zl} / 1000 \mathrm{~m}^{3}$ ),

- zmiana nakładów inwestycyjnych - rozkład trójkątny $(-10 \%, 0 \%, 20 \%)$. odpowiednio w tablicach 1 i 2 przy założeniu wartości najbardziej prawdopodobnych dla zmiennych losowych. Wartość średnia NPV projektu podstawowego wyniosła $-21,3 \mathrm{mln}$ zł (mediana -26,9 mln zł), odchylenie standardowe 1,0 mln zł, podczas gdy wartość średnia NPV projektu rozbudowy zdyskontowana również na początek pierwszego roku analizy była równa 33,8 $\mathrm{mln} \mathrm{zł}$ (mediana 26,8 $\mathrm{mln} \mathrm{zł}$ ), a odchylenie standardowe $80,7 \mathrm{mln} \mathrm{z}$.

Ponadto wyestymowano rozkład wartości bieżącej PV projektu rozbudowy (bez nakładów inwestycyjnych) zdyskontowanej na początek roku rozpoczęcia rozbudowy (rok 8.). Schemat przepływów pieniężnych do obliczenia wartości bieżącej projektu rozbudowy przedstawiono w tablicy 3 przy założeniu wartości najbardziej prawdopodobnych dla zmiennych losowych. Wartość średnia PV projektu rozbudowy wyniosła $245,8 \mathrm{mln}$ zł (mediana 235,9 mln zł), odchylenie standardowe 120,9 mln zł. Wartość średnia projektu rozbudowy stanowi wartość instrumentu podstawowego, podczas gdy nakłady inwestycyjne wynoszące 218,3 mln zł są ceną wykonania opcji. Odchylenie standardowe stopy wzrostu wartości bieżącej PV projektu rozbudowy dla pierwszego roku rozbudowy ${ }^{5}$, zgodnie z koncepcją MAD, posłużyło do wyznaczenia wartości opcji. Wartość średnia stopy wzrostu $r_{1}$ w pierwszym roku wyniosła $7,5 \%$, a odchylenie standardowe $40,4 \%$. Srednia stopa wzrostu PV dla kolejnych lat analizy jest równa $6,5 \%$, zatem nie odbiega ona znacząco od stopy wzrostu z pierwszego okresu.

Tablica 1. Schemat przepływów pieniężnych CF dla projektu podstawowego dla wartości najbardziej prawdopodobnych zmiennych losowych [mln zł]

\begin{tabular}{|c|c|c|c|c|c|c|c|c|c|c|c|}
\hline Lata & 1 & 2 & 3 & 4 & 5 & 6 & 7 & 8 & 9 & \\
\hline $\mathrm{CF}$ & $-66,4$ & $-88,6$ & $-96,1$ & $-118,2$ & $-35,9$ & $-26,8$ & $-37,2$ & 32,9 & 33,9 & $\ldots$ & 75,4 \\
\hline
\end{tabular}

Tablica 2. Schemat przepływów pieniężnych CF dla projektu rozbudowy magazynu dla wartości najbardziej prawdopodobnych zmiennych losowych [mln zł]

\begin{tabular}{|c|c|c|c|c|c|c|c|c|c|c|c|c|c|}
\hline Lata & 1 & 2 & 3 & 4 & 5 & 6 & 7 & 8 & 9 & 10 & 11 & 12 & 30 \\
\hline $\mathrm{CF}$ & - & - & - & - & - & - & - & $-49,6$ & $-45,0$ & $-58,6$ & $-31,8$ & 25,0 & 39,4 \\
\hline
\end{tabular}

Tablica 3. Schemat przepływów pieniężnych CF dla projektu rozbudowy magazynu służących do obliczenia wartości bieżącej projektu PV dla wartości najbardziej prawdopodobnych zmiennych losowych [mln zł]

\begin{tabular}{|c|c|c|c|c|c|c|c|c|c|c|c|c|c|c|}
\hline Lata & 1 & 2 & 3 & 4 & 5 & 6 & 7 & 8 & 9 & 10 & 11 & 12 & & 30 \\
\hline $\mathrm{CF}$ & - & - & - & - & - & - & - & - & 4,6 & 11,0 & 17,8 & 25,0 & $\ldots$ & 39,4 \\
\hline
\end{tabular}

Na tej podstawie w wyniku symulacji Monte Carlo uzyskano rozkłady prawdopodobieństwa wartości bieżącej netto NPV niezależnie dla obu projektów, zdyskontowane na pierwszy rok analizy. Schematy przepływów pieniężnych dla projektu podstawowego i projektu rozbudowy przedstawiono
Przyjmując wartość bieżącą rozbudowy jako wartość instrumentu podstawowego $S=245,9 \mathrm{mln}$ zł oraz stopę

${ }^{5}$ Liczonej według wzoru (5). 
wolną od ryzyka $r=2 \%$ i zakładając dwuletni okres do wygaśnięcia, obliczono wartość opcji, która wyniosła 70,7 mln zł. Sposób wyceny opcji rozbudowy PMG obrazuje rysunek 2. Główne wyniki symulacji i obliczeń zebrano w tablicy 4.

Przedsięwzięcie w podstawowym wariancie nierentowne po uwzględnieniu opcji rozszerzenia skali okazuje się rentowne, gdyż jego NPV wynosi 25,7 mln zł. Wynika to z możliwości rozbudowy magazynu w przyszłości w sprzyjających warunkach rynkowych. Co więcej, rentowności sprzyja brak przymusu rozbudowy magazynu w niesprzyjających warunkach i konieczności zbędnego ponoszenia nakładów inwestycyjnych. Jest to bowiem opcja rozbudowy, która ze swojej natury nie musi zostać zrealizowana.

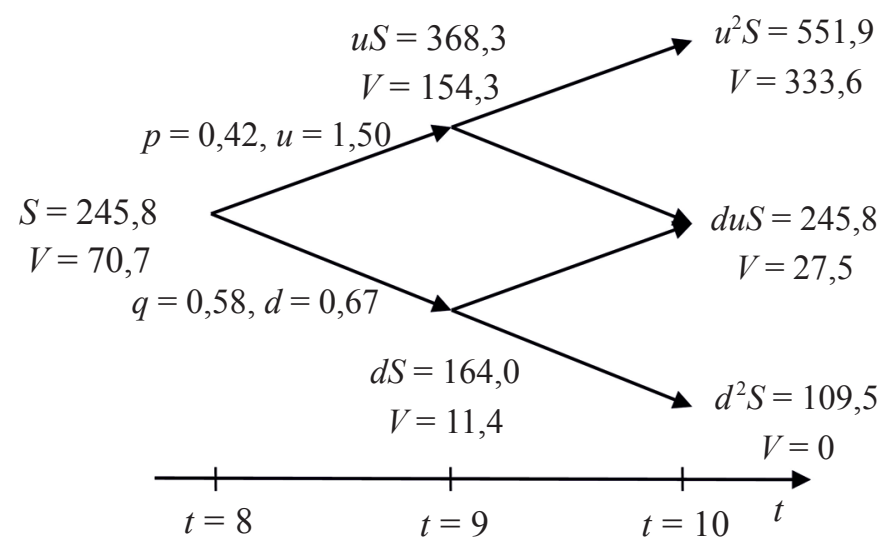

Rys. 2. Drzewo dwumianowe zmiany wartości instrumentu podstawowego $S$ (wartość bieżąca PV rozbudowy magazynu) w czasie wraz z wartością opcji $V$ w mln zł

Źródło: opracowanie własne.

Tablica 4. Wyniki symulacji oraz wyceny opcji rozszerzenia skali PMG

\begin{tabular}{|l|c|}
\hline \multicolumn{1}{|c|}{ Parametr } & Wartość \\
\hline Wartość oczekiwana NPV projektu podstawowego [mln zł] & $-21,3$ \\
\hline Wartość oczekiwana NPV rozbudowy magazynu [mln zł] & 33,8 \\
\hline Oczekiwana wartość bieżąca PV rozbudowy w 8. roku [mln zł] & 245,8 \\
\hline Odchylenie standardowe stopy wzrostu wartości rozbudowy $r_{t}[\%]$ & 40,4 \\
\hline Wartość oczekiwana NPV projektu wraz z rozbudową [mln zł] & 12,5 \\
\hline Wartość opcji rozszerzenia skali magazynu [mln zł] & 70,7 \\
\hline Wartość opcji zdyskontowana na początek 1. roku analizy [mln zł] & 47,0 \\
\hline Wartość oczekiwana NPV projektu wraz z opcją rozszerzenia & 25,7 \\
\hline
\end{tabular}

Źródło: opracowanie własne.

\section{Wnioski}

1. Zastosowanie opcji rzeczywistych pozwala na wycenę wartości dodatkowych działań inwestycyjnych podejmowanych w późniejszym okresie, już po rozpoczęciu realizacji przedsięwzięcia. Jest to bieżąca wartość decyzji strategicznych, które bez zastosowania opcji realnych były dotychczas podejmowane przez menedżerów w sposób jakościowy na podstawie ich wiedzy i doświadczenia.

2. Opcje rzeczywiste typu amerykańskiego ułatwiają wyznaczenie wartości przedsięwzięć możliwych do podjęcia w dłuższym okresie. W przemyśle naftowym proces decyzyjny może być rozłożony na kilka lub kilkanaście lat i dla tak długiej perspektywy może być wyliczona wartość opcji rzeczywistej. Realizacja opcji może nastąpić w dowolnym momencie całego przedziału czasu.
3. Wartość opcji rzeczywistej rozszerzenia skali dla przykładu liczbowego dotyczącego rozbudowy podziemnego magazynu gazu jest wyższa niż wartość bieżąca netto NPV rozbudowy PMG ze względu na możliwość rezygnacji z wykonania opcji w niesprzyjających warunkach rynkowych.

4. Wartość bieżąca netto w przykładzie liczbowym dotyczącym budowy podziemnego magazynu gazu jest ujemna, ale po uwzględnieniu opcji rozszerzenia skali staje się dodatnia. Jest to całkowita wartość magazynu biorąca pod uwagę potencjalną możliwość przyszłej rozbudowy magazynu w istniejącej lokalizacji w sprzyjających warunkach rynkowych. Opcja zwiększa wartość inwestycji o wartość decyzji strategicznej.

Prosimy cytować jako: Nafta-Gaz 2016, nr 1, s. 33-39, DOI: 10.18668/NG2016.01.04

Artykuł nadesłano do Redakcji 10.07.2015 r. Zatwierdzono do druku 29.10.2015 r.

Artykuł powstał na podstawie pracy statutowej pt. Zaawansowane metody i algorytmy komputerowego przetwarzania danych w zarządzaniu i technice, zleconej przez Ministerstwo Nauki i Szkolnictwa Wyższego, zlecenie wewnętrzne 11.11.200.274. 
Artykuł stanowi rozszerzoną wersję referatu wygłoszonego na Konferencji Geopetrol 2014, Zakopane 15-17 września 2014 r., opublikowanego pt. Opcje rzeczywiste jako narzędzie wspomagajace podejmowanie decyzji na przykładzie budowy podziemnego magazynu gazu, „Prace Naukowe Instytutu Nafty i Gazu” 2014, nr 198, s. 803-806.

\section{Literatura}

[1] Black F., Scholes M.: The Pricing of Options and Corporate Liabilities. Journal of Political Economy 1973, vol. 81, nr 3, s. 637-654.

[2] Copeland T., Antikarov V.: Real Options: A Practitioner's Guide. New York, Texere, 2001.

[3] Cox J., Ross S., Rubinstein M.: Option Pricing: A Simplified Approach. Journal of Financial Economics 1979, vol. 7, nr 3, s. 229-263.

[4] Felix B., Woll O., Weber C.: Gas Storage Valuation Under Limited Market Liquidity: An Application in Germany. University of Duisburg - Essen EWL Working Paper 2009, nr 5.

[5] Łucki Z.: Ocena inwestycji i podejmowanie decyzji w górnictwie naftowym i gazownictwie. Kraków, Polska Fundacja Promocji Kadr, 1995.

[6] Luenberger D.: Teoria inwestycji finansowych. Warszawa, Wydawnictwo Naukowe PWN, 2003.

[7] Manuel P., Godinho C.: Monte Carlo Estimation of Project Volatility for Real Options Analysis. Estudos Do GEMF 2006, nr 1.

[8] Mizerka J.: Opcje rzeczywiste w finansowej ocenie efektywności inwestycji. Poznań, Wydawnictwo Akademii Ekonomicznej w Poznaniu, 2005.

[9] Paliński A.: Ocena ryzyka finansowego budowy podziemnego magazynu gazu z wykorzystaniem symulacji Monte Carlo. Prace Instytutu Nafty i Gazu 2008, nr 150, s. 145-150.
[10] Qiu X., Wang Z., Xue Q.: Investment in deepwater oil and gas exploration projects: a multi-factor analysis with a real options model. Petroleum Science 2015, vol. 12, nr 3, s. 525-533.

[11] Rumbauskaite R.: Investment in Underground Gas Storage: A Real Options Approach. Tilburg University 2011, http:// www.tilburguniversity.edu (dostęp: październik 2015).

[12] Saługa P.: O referencyjnym i konsekutywnym instrumencie bazowym opcji rzeczowych. [W:] Marcinek K. (red.): Inwestowanie $w$ aktywa rzeczowe i finansowe. Studia Ekonomiczne Uniwersytetu Ekonomicznego w Katowicach 2013, nr 155, s. 402-418.

[13] Saługa P.: Wycena projektu górniczego z opcjami równoległymi. Gospodarka Surowcami Mineralnymi 2011, nr 1, s. 101-113.

[14] Wilimowska Z., Łukaniuk M.: Dwumianowy model wyceny opcji rzeczowych. Badania Operacyjne i Decyzje 2005, nr 1, s. $71-83$.

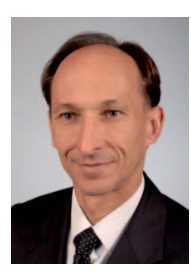

Dr hab. inż. Andrzej PALIŃSKI

Adiunkt

Akademia Górniczo-Hutnicza im. St. Staszica

w Krakowie, Wydział Zarządzania

ul. Gramatyka 10

30-067 Kraków

E-mail:palinski@zarz.agh.edu.pl 